\title{
NATIONAL SELF-DETERMINATION, AS UNDERSTOOD BY LENIN AND THE BOLSHEVIKS
}

\author{
Rudolf A. Mark
}

Abstract. The article gives an abridged introduction to the genesis of the term 'right to self-determination' from the mid-nineteenth century. It also illustrates the term's usage before and after the Bolshevik Revolution. The right to self-determination played a crucial role in the political discourse of socialist parties in Central and Eastern Europe on the eve of World War One. The Bolsheviks made use of the term as a slogan to fight imperialism and to make non-Russian nationalities side with the Soviet project of establishing the Union of Soviet Socialist Republics.

Introduction At the turn of 1917-18 due to Wilson's Fourteen Points programme the concept of the 'Right of Self-Determination' started to play an increasingly prominent part in world politics in general and in Europe in particular. The idea that the right to legitimate dominion rests upon the consent of the governed people had emerged in the Middle Ages and has been elaborated in the course of political thought over past centuries. In the nineteenth century it was in the context of the Polish question in 1865 that the 'right to self-determination' was first used in an official proclamation. On suggestion of Karl Marx, ${ }^{1}$ it was issued by the First International in order to mobilize the Polish population and to set it against Russian rule as the headline of the proclamation made clear: 'De la nécessité d'anéantir l'influence russe en Europe pour l'application du droit des peoples de disposer d'eux-mêmes et de reconstruire une Pologne sur des bases démocratiques et sociales'. ${ }^{2}$ One year later, Jarosław

${ }^{1}$ Cf. F. Mehring, Karl Marx. Geschichte seines Lebens (Leipzig, 1918), p. 359; C. Bobińska, Marx und Engels über die polnischen Probleme, (Berlin, 1958), pp. 256-257.

${ }^{2}$ La Première Internationale. Recueil de documents publié sous la direction de Jacque Freymond. Textes établis par Henri Burgelin, Knut Langfeldt et Miklós Molnár. Introduction par J. Freymond, I (Genève, 1962) [=Publications de l'Institut universitaire de hautes études internationales, 39], p. 35. 
Dąbrowski, member of the Polish National Central Committee, admonished the Polish émigré community to refrain from nationalist tendencies in their concepts and visions about the restoration of the Rzeczpospolita and to give the full right to national self-determination to Ukraine. ${ }^{3}$ Thus the concept showed that it could be used for partisanship, politics and propaganda. And indeed, during the whole period until the First World War and during the war 'the idea and postulate of self-determination was used and abused by idealists and machiavellists alike'. ${ }^{4}$

At the same time, the concept of the 'Right to self-determination' was a major issue in political discourse within the polyethnic empires in Europe with their unsolved nationalities questions. Moreover, it ranked high among the postulates and objectives which formed the more or less clear-cut programmes of the Socialist and Social Democratic Parties including the Bolsheviks. ${ }^{5}$ The Austrian Social Democrats played a leading role in the theoretical debate on the subject. At their Party Congress in September 1899 in Brünn, they had unanimously adopted the national federalisation of the Austrian Social Democratic Party but also a nationalities programme that envisaged - instead of the existing crown lands - ethnically defined autonomous political bodies of limited self-rule within the Habsburg empire. Moreover, these bodies of self-rule belonging to the same nation formed a national unit with complete autonomy in all national issues. ${ }^{6}$ The so called 'Austrian school' represented by

${ }^{3} \mathrm{~W}$. Suleja, 'Kresy wschodnie w myśli politycznej polskiej irredenty w okresie popowstaniowym (1864-1914)', Polska myśl polityczna XIX i XX wieku, VI: Między Polskq etnicznq a historyczna, ed. W. Wrzesiński (Wrocław, etc. 1988), p. 171; Bobińska, Marx und Engels, p. 264.

${ }^{4}$ K. Rabl, Das Selbstbestimmungsrecht der Völker (Munich, 1963), p. 270.

${ }^{5}$ Basic studies on the subject by R. Pipes, The Formation of the Soviet Union. Communism and Nationalism 1917-1923 (Cambridge, 1957); J.A. Armstrong, Nations before Nationalism (Chapel Hill, 1982); W. Connor, The National Question in Marxist-Leninist Theory and Strategy (Princeton, 1984); H.B. Davis, Toward a Marxist Theory of Nationalism (New York, 1978).

${ }^{6}$ R.A. Kann, Das Nationalitätenproblem der Habsburgermonarchie. Geschichte und Ideengehalt der nationalen Bestrebungen vom Vormärz bis zur Auflösung des Reiches im Jahre 1918, vol. 2: Ideen und Pläne zur Reichsreform, 2. erweiterte Aufl. (Graz/Köln 1964) (=Veröffentlichungen der Arbeitsgemeinschaft Ost, vol. 5), p. 161; H. Mommsen, 'Nationalismus, Nationalitätenfrage', Sowjetsystem und demokratische Gesellschaft. Eine vergleichende Enzyklopädie, IV: Lenin bis Periodisierung (Freiburg-Basel-Vienna, 1971), pp. 662-670. 
Otto Bauer (1882-1938) and Karl Renner (1870-1950) advocated a national and cultural concept combining personal and territorial autonomy (Personal- und Territorialautonomie) with national cultural autonomy (nationale und kulturelle Autonomie) ${ }^{7}$ that indeed had its bearing on the system the Bolsheviks later applied in the USSR. ${ }^{8}$ But in their lifetime, both Lenin and Stalin fought vigorously against the Austrian school. From their perspective the Austrian concept resembled the bourgeois nationalism in too many regards thus blurring the basic differences between both designs. Moreover, they kept labelling Renner's and Bauer's ideas, as well as those of the German Social Democrat Karl Kautsky (1854-1938), opportunistic, petit bourgeois and reactionary, arguing that they would result in rendering involuntary support to oppressor nations and undermine the unity of the working class. ${ }^{9}$

Quite different from Lenin and Stalin and, nota bene, from Kautsky, who considered national distinctions as ephemeral political phenomena which would disappear in the process of constructing a supranational society after the victory of the oncoming socialist revolution, in the perception of Renner and Bauer nations and nationalities were natural phenomena (Renner: Nations are 'von Natur aus gesondert' [separated by nature], 'natürlich gesonderte Elemente', Bauer: 'Naturgemeinschaft und Kulturgemeinschaft'), products of the natural development

${ }^{7}$ Synopticus [pseudonym of Karl Renner]: Staat und Nation. Zur österreichischen Nationalitätenfrage (Vienna, 1899); R. Springer (pseudonym of K. Renner), Der Kampf der österreichischen Nationen um den Staat, Teil I: Das nationale Problem als Verfassungs- und Verwaltungsfrage (Vienna, 1902); O. Bauer, Die Nationalitätenfrage und die Sozialdemokratie (Vienna, 1907) (=Marx-Studien. Blätter zur Theorie und Politik des wissenschaftlichen Sozialismus, 2), pp. 324-366; E.J. Nimni, 'The Nationalities Theory of Otto Bauer and Its Relevance to the Analysis of Contemporary National Formations', Otto Bauer (1881-1938). Theorie und Praxis. Beiträge zum wissenschaftlichen Symposium des Dr-Karl-Renner-Instituts, abgehalten von 20. bis 22. Oktober 1981 in Wien, ed. E. Fröschl, H. Zeitl (Vienna, 1985), pp. 113-126.

${ }^{8}$ Natsional'naia politika Rossii: istoria i sovremennost', ed. V.A. Mikhailov (Moscow, 1997), p. 285.

${ }^{9}$ Cf. V.I. Lenin, ' $\mathrm{K}$ istorii natsional'noi programmy v Avstrii i v Rossii', in: Idem, Sochineniia, 20 (Moscow, 1952), pp. 82-84; Idem, 'Kriticheskie zametki po natsional'nomu voprosu', in: Sochineniia, 20, pp. 17-23; Idem, 'Sotsialisticheskaia revolutsiia i prava natsii na samoopredelenie (tezisy)', in: Idem, Sochineniia, 22 (Moscow, 1952), pp. 136-37; I.V. Stalin, 'Marxism i natsional'nyi vopros', Stalin, Sochinenia, 2: 1907-1913 (Moscow, 1953), pp. 312-332; Idem, 'K postanovke natsional'nogo voporosa', in: Idem, Sochineniia, 5 (Moscow, 1952), p. 54. 
of mankind. ${ }^{10}$ Moreover, Renner's pronouncement that 'the nation, and only the nation has the right and the power to act in the world by its own initiative. There is no power superior to it...' ${ }^{11}$ was a blasphemy in the ears of any hard-core Bolshevik.

The Bolsheviks' View of the Right to Self-determination The situation in the Russian Empire, a multinational state - in the words of Marx: the 'prison house of peoples' - urged the Russian Social Democrats to deal with the aspirations to self-determination of peoples and national groups. On suggestion by the 'father of Russian Socialism' Georgii V. Plekhanov (1856-1918), already the first programme adopted at the Second Party Congress in 1903 contained a paragraph (9) stipulating the 'right to self-determination of all nations belonging to the united state' (sostav gosudarstva). ${ }^{12}$ Already at this point in time, however, Lenin underlined in a comment that the task of the Social Democrats was not to support and foster the self-determination of peoples and nations in general, but the self-determination of the proletariat as it existed within every nationality. Moreover, the unification of the proletariat of all these nations and nationalities was the main objective, while the acceptance of the creation of new separate class states or even a weak sort of federation had to be an exception to the rule. ${ }^{13}$ The stipulation of the right to self-determination in the communist programme was probably induced by the resolution of the Socialist International in London in $1896^{14}$ and soon became an issue hotly disputed within

${ }^{10} \mathrm{~K}$. Renner, Das Selbstbestimmungsrecht der Nationen in besonderer Anwendung auf Oesterreich. Zugleich zweite vollständig umgearbeitete Auflage von des Verfassers Buch ,,der Kampf der österreichischen Nationen um den Staat. Erster Teil: Nation und Staat" (Leipzig-Vienna, 1918), p. 234; Bauer, Die Nationalitätenfrage, pp. 22-26.

${ }^{11}$ Renner, Das Selbstbestimmungsrecht, p. 9.

12 Programma Rossiiskoi Sotsial-Demokratichnoi Rabochei Partii. Priniaty II s"ezdom RSDRP (Briussel'-London 17 (30) iiulia - 10(23) avgusta 1903 g.), in: Programmy i ustavy KPSS (Moscow, 1969), p. 24; J. Chlebowczyk, Między dyktatem, realiami a prawem do samostanowienia. Prawo do samookréslenia i problem granic we wschodniej Europie Środkowej w pierwszej wojnie światowej oraz po jej zakończeniu (Warsaw, 1988), p. 270.

${ }^{13}$ Lenin, 'Natsional'nyi vopros v nashei programme', idem, Sochineniia, 6 (Moscow, 1950), p. 412.

${ }^{14}$ Cf. Lenin, 'Sotsialisticheskaia revoliutsiya i pravo natsii', p. 144; M.I. Smirnova, 'Natsional'nye politicheskie partii Rossii sotsial-demokraticheskogo napravleniia (konets XIX-nachalo XX v.)', Istoriia natsional'nykh politicheskikh partii Rossii. Materialy mezhdunarodnoi konferentsii. Moskva. 21-22 maia 1996 g. (Moscow, 1997), pp. 141-144. 
the Marxist socialist movement. Most prominent protagonists were Rosa Luxemburg who placed social questions, class interests and the fostering of internationalism above the nationalities issue, and Lenin, assisted by Stalin, the Bolsheviks' master of the nationalities Question'15.

It was on the eve of World War One, when the debate on the nationalities question was resumed by the Mensheviks and national organisations such as the Bund, the Latvian and Caucasian Social Democrats and the Polish and Lithuanian socialist parties in 1912, forcing Lenin and Stalin to respond. There is some reason to assume that both Bolshevik leaders were particularly provoked by the Austrian Marxist concept of national cultural autonomy obviously gaining increasing acceptance among RSDRP-members. ${ }^{16}$

Stalin, with whom Lenin was in fundamental agreement on all essential aspects of the nationalities problem, presented the first Bolshevik theory on the subject in his article 'Marxism and the National Question'. This study was written under Lenin's supervision and with the assistance of Nikolai Bukharin (1888-1938). In this article Stalin started his explanations with a definition of the term 'nation' (natsia). In his words 'A nation is a historically originated stable community of people, originated on the basis of a common language, common territory, joint economic life and common mental characteristics revealing themselves in a common culture'. ${ }^{17}$ Parallel to Stalin, Lenin had to elaborate and formulate the fitting political strategy. This strategy aimed at using the peoples' right to self-determination to undermine and destabilize the tsarist regime. To understand Lenin's concept it is helpful to distinguish between two analytical levels respectively two dimensions of the slogan and its meaning.

The Theoretical-Ideological Dimension When formulating his concept Lenin had to combine two essential aspects into one theory: First he had to elaborate and point out the close context of the nationalities question as the political right to self-determination and the expected revolution, and secondly he had to find a formula, which

15 T. Martin, The Affirmative Action Empire. Nations and Nationalism in the Soviet Union, 1923-1939 (Ithaca-London, 2001), p. 3.

${ }^{16}$ Stalin, 'Na puti k natsionalizmu (Pis'mo s Kavkaza)', idem, Sochineniia, 2, pp. 284-289.

${ }^{17}$ Stalin, 'Marksizm i natsional'nyi vopros', idem, Sochineniia, 2, p. 296. 
was compatible with his ideas of democratic centralism, as defined by him in the dispute with the Mensheviks in 1905/6 - that is the top to bottom principle, upon which the structure of the Russian Social Democratic Worker Party was based.

Lenin came to the realization that there was a close connection and interdependence between the emerging bourgeois capitalism and national movements. To overcome feudalism, capitalism had to bring about the conquest of the inner market by the bourgeoisie and to unify territories inhabited by a population sharing the same language, as it also was the objective of the national movements. ${ }^{18}$ Moreover, the national struggle was not only a matter of bourgeois nationalism, but an obligation of Marxists and democrats in general. Lenin made a point of arguing that in reality this struggle meant fighting for common rights of nations and languages and fighting national oppression, and, by their nature Marxists had to fight any kind of oppression, injustice, and inequality. A further observation Lenin made was the 'fact...that the formation of independent national states is a tendency in all bourgeois-democratic revolutions'. Therefore, Marxists had to realize that the term 'self-determination of nations' was tantamount to 'political self-determination, independence (' $\mathrm{go}$ sudarstvennaia samostoiatel'nost'), formation of a national state'. ${ }^{19}$ He went even further arguing that Russian Socialists who neglected this aspect and failed 'to demand freedom of secession for Finland, Poland, the Ukraine, etc., etc. - are behaving like chauvinists, like lackeys of the blood-and-mud-stained imperialist monarchies and the imperialist bourgeoisie'. ${ }^{20}$ The emergence of capitalism, nations and national states was a historic fact, a development that was not to be impeded, because its accomplishment was seen as a precondition for the socialist revolution. Capitalism, would turn the settled Russian and Ukrainian peasants into mobile proletarians. The freer Ukraine and Russia were to become, the wider and faster would be the capitalist development which would attract the labourers of all nations and all parts of the empire and the neighbouring countries. As a result, there would take place progressive assimilation and

${ }^{18}$ Lenin, 'O prave natsii na samoopredelenie', idem, Sochineniia, 20 (Moscow, 1952), p. 368; idem, 'Kriticheskie zametki po natsional'nomu voprosu' idem, Sochineniia, 20, pp. 11, 32.

${ }^{19}$ Lenin, 'O prave natsii na samoopredelenie', p. 372.

${ }^{20}$ Lenin, 'Sotsialisticheskaia revoliutsiia i pravo natsii', p. 142. 
melting of these nations similar to processes in America. ${ }^{21}$ And a precondition of the socialist Revolution was the existence of a proletariat that was above all class-conscious and united.

However, things were complicated with regard to Russia where the proletariat of both the oppressed and the oppressor nations were fighting side by side. But Lenin was concerned that the unity of the proletariat was threatened by Great-Russian chauvinism. So, Lenin's theoretical sophistication was challenged to the utmost, when he wrote his solution to the problem by combining the right to self-determination with the revolutionary Bolshevik strategy of internationalism. In his article: On the right of nations to self-determination (spring 1914) he explained his views stating that the proletariat of Russia had to face a two-sided task:

to fight every kind of nationalism, above all Great Russian nationalism; to recognize, not only fully equal rights for all nations in general, but also equal rights with regard to the construction of state [gosudarstvennogo stroitel'stva], that is the right to self-determination, to secession; - at the same time, it is their task, in the interests of a successful struggle against all and every kind of nationalism among all nations, to preserve the unity of the proletarian struggle and the proletarian organisations, merging these organisations into a very close international association, contrary to the bourgeois strivings for national exclusiveness. ${ }^{22}$

As Lenin used to argue, the right to self-determination entailed the right to secession to political separation from a oppressor state, as was the case with the Russian Empire. Especially oppressed nationalities in the periphery, whose co-nationals lived across the border enjoying a higher degree of national independence as for instance Finns, Swedes, Ukrainians, Poles, Rumanians should therefore possess that right. However, at the same time, Lenin indicated that in most cases separatism and separation were no real threat, thanks to the mass of the populations. Lenin argued that

From their daily experience the masses of population know very well the significance of geographical and economic ties, the advantages of a big market and a big state; they will, therefore, resort to secession only when national oppression and national friction make joint life absolutely intolerable and hinder all and any economic relations. In that case, the interests of capitalist development and of freedom of the class struggle will be best preserved by secession. ${ }^{23}$

${ }^{21}$ Lenin, 'Kriticheskie zametki', p. 15.

${ }^{22}$ Lenin, 'O prave natsii na samoopredelenie', p. 423.

${ }^{23}$ Ibid., p. 394. 
The Political and Tactical Dimension In 1916, in the middle of the war, when, not only in the context of the Polish and Lithuanian question, the nationalities issue had reappeared on the political agenda of the central powers, Lenin had to reconsider his concept of self-determination respectively to explain its mode and range of application. Moreover, Wilson's Fourteen Points stipulating national self-determination gave the issue additional significance. In his view, the right of nations to self-determination was not a right, any nation or people could demand by dint of history, cultural development, natural law and alike. Lenin used its proclamation as a tactical means. The striving of peoples and nations for national emancipation, i. e. the national movements were to be recruited to enlarge the ranks of socialist revolutionaries fighting imperialism all over the world. Or, as Lenin stated:

Just as mankind can achieve the abolition of classes only by passing through the transition period of the dictatorship of the oppressed class, so mankind can proceed towards the inevitable fusion of nations only through a transitional period of the complete freedom of all the oppressed nations, that is their freedom to secede. ${ }^{24}$ In practice, the right was restricted in several regards:

1. According to Lenin, it was exclusively the right 'to free, political separation from the oppressor nation'. It implied 'complete freedom to agitate for secession' and nota bene 'for a referendum for secession by the seceding nation'. Therefore it was not 'the equivalent of a demand for separation, fragmentation and the formation of small states' but 'merely the logical expression of the struggle against national oppression in every form' ${ }^{25}$

2. The right to freely secede was not be confused with the 'advisability of secession by a given nation at a given moment' as Lenin stated at the Seventh All-Russian Conference of the Bolshevik Party in May 1917. And of course, it had to be the party of the proletariat to decide that question 'quite independently in each particular case, having regard to the interests of social development as a whole and the interests of the class struggle of the proletariat for socialism $[\ldots]^{\prime 26}$

${ }^{24}$ Lenin, 'Sotsialisticheskaia revoliutsiia i prava natsii', pp. 136-137.

${ }^{25}$ Ibid., p. 135.

${ }^{26}$ Quoted from W. Sukiennicki, East Central Europe during World War I: From Foreign Domination to National Independence, ed. M. Siekierski, vol. I (New York, 1984) (=East European Monographs, No. CXIX), p. 456. 
3. The right was restricted to people under colonial rule respectively to nations inhabiting the periphery of the European empires encompassing the British Empire and Ireland as well as the German, Austrian and Russian empires, where socialists had to demand freedom of secession for Finns, Poles, Ukrainians etc. Therefore, the right did not apply to the population within the Russian territory proper, for which even the idea of creating a federal structure was rejected.

4. The third restriction existed with regard to the institution that would have the competence of decision. It goes without saying that Lenin envisaged the Bolshevik party to exert the supreme decision-making powers, since the party was seen as the embodiment of the will of the masses. And as mentioned above, the masses were supposed to appreciate unity and internationalism more than fragmentation and national separation. And as Stalin would underline in all his statements on the nationalities issue, nations, tribes and nationalities had a right to self-determination separation included, but whatever decision was made it had to be in the masses' interest. However, the demand to separate the periphery of Russia in the given period of revolution was not in the masses' interest because it was a 'deeply counter-revolutionary' demand as Stalin termed it. ${ }^{27}$ In other words, the principle of self-determination was just a means in the struggle for socialism and subordinated to the principles of socialism. It turned into an empty slogan ('pustoi lozung') having served its purpose as a propaganda tool. ${ }^{28}$

Despite all these restrictions the concept of Lenin and Stalin met with strong objections within the Bolshevik party, with Yurii Piatakov (1890-1937), Nikolai Bukharin, and Feliks Dzerzhinskii (1877-1926) being the most prominent critics. Therefore Lenin, assisted by Stalin, had to use his entire authority to get his concept accepted by a majority at the party conference in April $1917 .{ }^{29}$ At the end of the

${ }^{27}$ Stalin, 'Politika sovietskoi vlasti po natsional'nomu voprosu v Rossii', idem, Sochineniia, 4 (Moscow, 1950), pp. 353-354.

${ }^{28}$ Stalin, 'Doklad ob ocherednykh zadachakh partii v natsional'nom voprose (X. s'ezd RKP(b), 10 marta 1922), in: idem, Sochineniia, 5: 1921-1923 (Moscow, 1952), p. 42; cf. Stalin, 'Zakliuchitel'noe slovo po dokladu o natsional'nykh momentakh v partiinom i gosudarstvennom stroitel'stve (XII s'ezd RKP(b), 25 aprelia 1923), in: ibid., p. 265; G. Simon, Nationalismus und Nationalitätenpolitik in der Sowjetunion. Von der totalitären Diktatur zur nachstalinschen Gesellschaft (BadenBaden, 1986) (=Osteuropa und der internationale Kommunismus, 16), pp. 34-40; Chlebowczyk, Między dyktatem, p. 276.

${ }^{29}$ H. Carrère d'Encausse, Lenin (Munich etc., 2000), p. 385. 
day, his concept was approved and could then serve as propaganda during the Civil war, when the national question occurred to be an issue that had to be considered by all sides. It could be used to establish soviet rule in the periphery, where centrifugal tendencies had become a serious threat to the empire's unity.

\section{The Formation of the Soviet Union and the Right to National} Self-determination The term federalism respectively federalisation which had been denounced as a reactionary concept before, was rehabilitated with the Bolsheviks strivings to seize power. In a letter to S. G. Shaumian in December 1913 Lenin had argued that the Bolsheviks carried on adhering to the principle of democratic centralism: 'In principle, we are against federation - it weakens economic ties, and is an unsuited kind of a state[...] Autonomy is our design of building a democratic state $[\ldots],{ }^{30}$ Now, federalism was understood as the right to national autonomy on the level of oblasts and regions within Russia proper, because, as Stalin argued, federalism had 'turned out to be not so clearly in contradiction with the goal of economic unification as it might have seemed earlier'. ${ }^{31}$ The First All-Russian Congress of Soviets in June 1917, endorsed that concept as a 'path of governmental decentralisation'. ${ }^{32}$ Moreover, it was reaffirmed on the Second Congress in October 1917, and eventually its principles were listed in the Declaration of the Rights of the Peoples of Russia in November of the same year. It stipulated:

1. The equality and sovereignty of the peoples of Russia.

2. The right of the peoples of Russia to free self-determination, up to the point of separation and the creation of an independent state.

3. The abolition of any and all national and national-religious privileges and restrictions.

4. The free development of national minorities and ethnographic groups living on the territory of Russia. ${ }^{33}$

${ }^{30}$ Quoted from V.A. Shishkin, 'Ustroi sovetskogo federalizma v gody stanovleniia edinogo soiuznogo gosudarstva (1922-1929)', in: Rossia v XX veke, p. 292.

${ }^{31}$ Stalin, 'Protiv federatsii' (1923), quoted from Martin, The Affirmative Action Empire, p. 14.

32 Sukiennicki, East Central Europe, p. 306.

33 'Deklaratsiia prav narodov Rossii', Istoriia sovetskoi konstitutsii (v dokumentakh) 1917-1956, ed. A.A. Lipatov, N.T. Savenkov, S.S. Studenikina (Moscow, 1957), pp. 57-58. 
As time would approve, this concept had a provisional and transitional character. It was but a tactical means of the Bolsheviks on the path from the compulsory unitarism of the tsarist regime to the 'voluntary and fraternal unity of the working masses of all nations and tribes of Russia' in future time, as Stalin underlined in April 1918 when he was dwelling on the structure and organization of the prospective Russian republic, the RSFSR. ${ }^{34}$

The transitional character of the concept was once more reaffirmed by paragraph 9 of the second Party programme adopted on the Eighth Party Congress in March 1919. Whereas Chapter 9.2 stipulated equal rights to all nations and the right to separation of colonies and nations lacking equal rights, Chapter 9.3 defined federalism as another one of the 'transitional forms on the way to full unity'. ${ }^{35}$ In practice, however, the right to secession and separation has been reduced to the question of power, that is, the Bolsheviks' capability of gaining control over Russia's neighbouring countries and nations. Already in November 1917, after the formation of the Bolshevik government, Stalin as People's Commissar for Nationalities revealed the dialectical strategy pursued by the Soviets in this regard. Defending the right to free self-determination of Finland he argued that the Bolsheviks would be betraying democracy and socialism if they did not do 'everything to restore fraternal confidence between the workers of Finland and Russia' by recognizing the right to selfdetermination. Further he underlined that it was

important that the verbal recognition will indeed be confirmed by the Council of People Commissars and that it will be put in effect without any hesitation, because the time for words has passed. The time has come when the old slogan 'Workers of all countries, unite!' must be put into effect [...] A voluntary and honest alliance of the Finnish people and the Russian people.

Because only by uniting, the peoples can secure and consolidate the achievements of the October revolution and foster the cause of the international socialist revolution. ${ }^{36}$ And in order to make clear the meaning of his sentences he advised the Finish Social Democrats to

\footnotetext{
${ }^{34}$ Stalin, 'Organizatsiia Rossiiskoi Federativnoi Respubliki' (Beseda s sotrudnikom gazety Pravda), idem, Sochineniia, 4, pp. 72-73.

35 'Programma Rossiiskoi kommunisticheskoi Partii (bolshevikov). Priniata VIII s'ezdom RKP(b) (Moskva, 18-23 marta 1919 g.)', Programmy $i$ ustavy, pp. 39-40.

${ }^{36}$ Stalin, 'Rech' na s'ezde finliandskoi sotsial-demokraticheskoi rabotnichei partii v Gel'singforse, 14 noiabria 1917 g.', Stalin, Sochineniia, 4, pp. 3-4.
} 
assume power by force, and if support should be needed the Bolsheviks were ready to render it. ${ }^{37} \mathrm{~A}$ month later, Stalin argued that the Council of Peoples Commissars had to recognize Finland's demand for independence, 'because if a nation demands the recognition of its independence through his representatives, a proletarian government departing from the principle of recognition of the right to self-determination has to meet this demand'. At the same time, however, he reproached the Finnish Social Democrats for their cowardice in the face of the Finnish bourgeoisie and their being incapable of tearing state power from the bourgeoisie's hands. ${ }^{38}$

As we know now, Finland declared independence from Russia in December 1917, and having failed to prevent the separation, the Soviet government had to recognize it. The same holds true with regard to the Baltic region, where national governments could be established, due to protection by the German occupation forces and due to the support by large parts of a nationally conscious population.

The unexpected strength of nationalism during the Russian civil war had to be taken into consideration by the Bolsheviks building an new polyethnic Soviet state, which was threatened by separatism in his periphery. By the Treaty of Brest-Litovsk, Soviet Russia had had to abandon her entire western territories, where Ukrainians and Belarusians cooperated with the Central Powers, and where the Ukrainian People's Republic kept her flag flying until the end of the Polish-Soviet war; in Bessarabia separatists supported Rumania's conquest of the region, and in the Caucasus Armenians, Azerbaijanis and Georgians fought for independence - helped by the British, the Turks, and the Germans. Soviet control over Central Asia, too, was jeopardized by counterrevolutionary forces and national movements. Among them ideas of national self-determination, of Turanism, PanIslamism and Panturkism were gaining momentum, and movements as for instance Alash Orda or Itil-Ural were perceived as threatening the cohesion and unity of the Soviet state. ${ }^{39}$ So, Lenin and the Bolshevik leadership had to react to the situation. They had to make concessions to the aspirations for sovereignty and independence.

${ }^{37}$ Ibid., p. 5.

${ }^{38}$ Stalin, 'O nezavisimosti Finliandii. Doklad na zasedanii VTsIK 22 dekabria 1917 g.' (Gazetnyi otchet), idem, Sochineniia, 4, pp. 22-24.

${ }^{39}$ A. Bennigsen, M. Broxup, The Islamic Threat to the Soviet State (LondonCanberra, 1983), pp. 36-37; Carrère d'Encausse, 'Civil War and New Governments', Central Asia. 130 Years of Russian Dominance. A Historical Overview, 3, ed. E. Allworth (Durham-London, 1994), pp. 236-237; M. Brill Olcott, The Kazakhs, (Stanford, 1995), pp. 136-148. 
And so they did. First efforts were made as early as 1918, when the Bolsheviks adopted a declaration which secured far reaching cultural and religious privileges to the Islamic peoples. At the same time, in Ukraine, the first attempts to establish Soviet rule had failed, to a high degree because the Bolsheviks had been unable to attract the masses of the rural population. Consequently, new attempts had to be facilitated by new approaches.

Therefore, now, the earlier condemned concept of federalism was re-introduced as the only realistic way to consolidate the precarious situation and to prevent the Soviet state from falling apart. The Bolsheviks had to accept national colours and develop a federal state structure based on national territories, in order to foster integration and to root the regime among the non-Russian population. Otherwise, they held up the principle: 'not an inch of the historical patrimony was to be yielded'. ${ }^{40}$

While Finland, Poland, the Baltic Region, and Bessarabia were lost to the Bolsheviks, the larger part of Ukraine and Belorussia, the south Caucasian republics and Central Asia were not. Due to the considerable internal weaknesses of the national movements in Ukraine and Belarus but also to external factors as foreign interventions and the Entente respectively the Paris peace conference turning its back on the Ukrainian strivings for independence the Bolsheviks could seize power in the western periphery of the former empire. The situation in the Caucasus was even more complicated. There, Moscow's rapprochement with Kemal Atatürk's Turkey, unrest among the north Caucasian Mountaineers, interethnic tensions and the inability of the Transcaucasians to bring about a joint defence against the Red Army had facilitated the re-conquest of this strategically important region. The control over it was crucial for the Soviet state to improve territorial security, to end diplomatic and economic isolation, and to prevent 'capitalist encirclement', an imminent threat since any hope for a proletarian revolution in Germany and Western Europe had faded away. ${ }^{41}$ Central Asia respectively Turkestan

${ }^{40}$ M. Crawford Young, 'The National and Colonial Question and Marxism: A View from the South', Thinking Theoretically about Soviet Nationalities. History and Comparison in the Study of the USSR, ed. A.J. Motyl (New York, 1992), p. 85.

${ }^{41}$ J. Jacobson, When the Soviet Union Entered World Politics (Berkeley-Los Angeles-London, 1994), p. 115; U. Halbach, Das sowjetische Vielvölkerimperium. Nationalitätenpolitik und nationale Frage (Mannheim etc., 1992), pp. 26-27; R.H. Donaldson, J.L. Nogee, The Foreign Policy of Russia. Changing Systems, Enduring Interests (New York-London, 2002), p. 56. 
had been a zone where British, Turkish and Soviet agents fought each other and where indigenous resistance was organized by the Basmachirebels. Also involved were Afghanistan and the former Emirate respectively the Khanate of Bukhara and Khiva. In both principalities the monarchies had been replaced by the Bukharan People's Republic and the Khwarezm People's Republic but, in the meantime, both underlay ongoing attempts of communist groups to transform theses countries into socialist republics which were to join the united Soviet state to come. So, they lost independence and freedom in 1924 when they were incorporated into the USSR in which they were refused the status of a subject of the Union that is the status of a SSR. Instead - with first territorial reorganizations accomplished - they formed part of the RSFSR. ${ }^{42}$ One year before the integration, Stalin made clear the reasons why these Central Asian republics were put under direct control of Moscow. Turkestan was the most important region within the Soviet Union, because from there, the revolution in the East would take its start. In Turkestan, lived a great number of nationalities of the East, and geographically it was situated in the very centre of that East,

which is exploited most, and which has accumulated the largest amount of explosive for the struggle against imperialism. This is why contemporary Turkestan is the weakest spot of Soviet power.' Consequently, it had to be 'turned into a model republic, a convenient outpost for triggering revolution in the East. ${ }^{43}$

However, there were the questions, how to re-integrate these regions, and in which form the right to self-determination should be enacted. As before, the party was split regarding this issue. Stalin, People's Commissar of Nationalities supported by others leading communists (Dzerzhinskii, Ordzhonikidze) advocated a state structure based on 'autonomisation' i. e. the enlargement of the RSFSR as a unitary state while allowing a more or less significant degree of autonomy to nations and nationalities. Lenin, however, was in favour of a federal solution, at least for the time being. In his view, autonomisation would lead to russification and limitation of sovereignty of the national units. The term, used in Stalin's plan, 'adhesion' (prisoedi-

\footnotetext{
${ }^{42}$ For more details see Carrère d'Encausse: 'The National Republics Lose Their Independence', Central Asia. 130 Years, pp. 254-257; M. Abdullaev, S.S. Agzamkhodzhaev, I.A. Alimov et. al., Turkestan v nachale XX veka: $K$ istorii istokov natsional'noi nezavisimosti (Tashkent, 2000), pp. 379-413; Jacobsen, When the Soviet Union, pp. 68-77; Bennigsen; Broxup, The Islamic Threat, pp. 41-42.

${ }^{43}$ Stalin, 'Chetvertoe soveshchanie TsK RKP(b) s otvetstvennymi rabotnikami natsional'nykh respublik i oblastei, 9-12 iiunia 1923 g.', Sochineniia, 5, p. 329.
} 
nenie) of Belarus, Ukraine, Georgia, Armenia, Azerbaijan, Bukhara and Khwarezm evoked Lenin's concern. These formally independent states, of which some signed international treaties with Germany, Austria, Poland, Italy and other countries between 1920 and 1923, and which had concluded 'Workers and Peasant Union Treaties' (Soiuznye raboche-krest'anskie dogovory) or similar conventions in 1920 and 1921 with the RSFSR, ${ }^{44}$ were now to be incorporated into Russia as autonomous republics subordinated to the Russian federal government and its institutions. As a result, so Lenin's argument, they would fall victim to Great-Russian chauvinism and a Russian apparatus taken over from tsarism, and only 'slightly anointed with Soviet oil', as Lenin put it.

On these conditions it is quite natural that the 'freedom to secede from the union', by which we justify ourselves, appears to be but a clean sheet of paper, unable to defend the non-Russians from the onslaught of that really Russian man, the Great-Russian, the chauvinist, in substance the rascal and violent rogue, such as the typical Russian bureaucrat is. ${ }^{45}$

At this point in time Lenin was still holding out hopes for the world revolution that would start in the eastern parts of the Eurasian continent. ${ }^{46}$ This is why he insisted on handling the nationalities issue with care and avoiding formulas which could be misunderstood by nations and nationalities in Russia's periphery and beyond. Under the terms of the Treaty of Riga, for instance, millions of Ukrainians and Belarusians were turned into citizens of the restored Rzeczpospolita. Thus, the Soviet border cut through the ethnographic territory of Belorusians and Ukrainians, but also of Finns and Rumanians. The Bolsheviks, however, were far away from abandoning their claims to these territories under foreign rule. They hoped that an ostentatiously generous treatment of those nationalities within the Soviet Union would attract their ethnic brethren in Poland, Finland, and Rumania. The creation of a Moldavian Autonomous SSR within the Ukrainian SSR in 1924 made these intentions obvious. ${ }^{47}$

${ }^{44}$ The treaties in: Istoriia sovetskoi konstitutsii, pp. 237-274; S.V. Kul'chyts'kii, 'USSR v 1917-1922 godakh: kharakter i predely sovetskoi natsional'noi gosudarstvennosti', in: Rossiia v XX veke. Problemy natsional'nykh otnoshenii. A.N. Sakharov, V.A. Mikhailov (Moscow, 1999), p. 230.

${ }^{45}$ Lenin, 'K voprosu o natsional'nostiakh ili ob "avtonomizatsii"', Istoria sovetskoi konstitutsii, p. 400.

${ }^{46}$ Cf. Lenin, 'K voprosu o natsional'nostiakh ili ob "avtonomizatsii”' (Prodolzhenie)', Istoriia sovetskoi konstitutsii, p. 404; Natsional'naia politika Rossii, pp. 261-263.

${ }^{47}$ Cf. Martin, The Affirmative Action Empire, p. 9. 
Due to Lenin's concerns, but also because autonomization met with objections from the republics in question - except for Azerbaijan and Armenia - Stalin's project, submitted in August 1922, was turned down. Later a revised text containing Lenin's amendments and adopted by the Central Committee in October 1922 became the cornerstone of the final agreement of the new state. The Bolshevik leader insisted on the non-Russian republics sharing equal rights with the RSFSR and joining it on an equal footing in a common state. Otherwise, the cohesion and consolidation of the new Federation would have been threatened from the start, as Lenin argued with regard to the strength of national forces in Ukraine and in the Caucasus. Therefore, the terms 'adhesion' respectively 'access' to the RSFSR were replaced by the formula 'formal union with the RSFSR within the framework of a Union of the Soviet Republics of Europe and Asia' 48 respectively: The Republics 'unite themselves in one federal State - "The Union of Soviet Socialist Republics" as was the wording in the 1924 Constitution.

The year before, proposals by the Ukrainian Bolshevik leaders Khristian Rakovskii (1873-1941) and Mykola Skrypnyk (1872-1933) at the Twelfth Party Congress to form a confederation instead of a union state, had been rejected. Lenin's and Stalin's permanent usage of terms like 'independent', 'sovereign', 'voluntarily', 'selfdetermination' and so on with regard to the republics had been to some unintended effect. A couple of Party members were indeed moved to think that the issue was about independent states to form a union based on mutually agreed treaties. Moreover, in December 1922, P. Sologub, a representative of the Soviet Ukrainian government, had made utterances which seemed to indicate that the prospective Union of republics would be realized in the form of a confederation. But a confederation structure was not in compliance with the Bolshevik concept of a coherent Soviet state. ${ }^{49}$ Even suggestions by Ukrainian communists to grant real autonomy to Khar'kiv were rejected by the Bolshevik leadership. Moreover, Rakovskii who advocated broad rights to all non-Russian republics, was eventually dismissed as Head of state of Ukraine. ${ }^{50}$ Besides

${ }^{48}$ Quoted from Halbach, Das sowjetische Vielvölkerimperium, p. 30.

${ }^{49}$ C. Stalin, Chetvertoe soveshchanie, pp. 340-341.

${ }^{50}$ For more details see J.E. Mace, Communism and the Dilemmas of National Liberation. National Communism in Soviet Ukraine, 1918-1933 (Cambridge, 1983), pp. 71-72; F. Conte, 'The Foreign Policy of the Soviet Ukraine and Its Domestic 
Stalin and others already mentioned, the opposition to the federation/ confederation concept favouring autonomization was also headed by prominent non-Russian communists as for instance the Ukrainian Dmytro Manuils'kii (1883-1959), the Georgian P. G. Mdivani and the Turk-Tatar enlightener and spokesman Mir Said Sultan-Galiev (1880-1939?). They advocated an autonomous status even on the level of the republics uniting with the RSFSR. ${ }^{51}$ At the same time, however, to them incorporation and sovietization of non-Russian territories of the future Union state 'did not mean acceptance of Great-Russian domination: on the contrary, it meant freedom from Russian domination and control'. ${ }^{52}$

Accordingly, Ukraine, Belarus and the Transcaucasian Federation were to form a Union of Socialist Soviet Republics (SSR), each with the right to secede, to freely withdraw from this federation (II, art. 4). ${ }^{53}$ At the same time, the Communist Party and its institutions remained unitary. Thus, these rights - as well as many others bestowed upon the SSRs by the constitution - remained purely formal, the party being the decisive instance on all levels of the USSR. ${ }^{54}$ This was also the case during the period of korenizatsiia, when the Bolsheviks made enormous attempts to come to terms with the national aspirations of the incorporated non-Russian republics by implementing the policy of indigenisation which was adopted by the Twelfth Party Congress in April 1923.

The reasons why the foundation of a union of Soviet republics was inevitable were explained in the declarative part of the Soviet constitution. Accordingly, it was the division of the world into the capitalist and Socialist camps, antagonistically confronted with each other, that has determined events. 'The attempts made by the capitalistic world during the past ten years to decide the question of nationalities ... have been fruitless ... The bourgeoisie has proven itself incapable of realizing a harmonious collaboration of the peoples.' Consequently, it was the Socialist camp that provided the real alternative: 'Here, in the camp of Socialism: reciprocal confidence

Implications 1919-1923', G. Gorodetsky, (ed.): Soviet Foreign Policy 1917-1991. A Retrospective (London, 1994), pp. 48-49.

${ }^{51}$ Natsional'naia politika Rossii, p. 269.

52 Bennigsen, Broxup, The Islamic Threat, p. 83.

${ }^{53}$ Stalin, 'Vopros ob ob'edinenii nezavisimykh natsional'nykh respublik'. Beseda s korrespondentom gazety Pravda, Idem, Sochineniia, 5, p. 153.

${ }^{54}$ T.G. Arkhipova, 'Unitarnyi kharakter ustroistva SSSR', Rossiia $v X X$ veke, pp. 280-287. 
and peace, national liberty and equality, the pacific co-existence and fraternal collaboration of the peoples.' (Part I, Declaration).

However, behind the façade of Lenin's Federation, which was never understood other than being declarative, and due to prevailing circumstances, Stalin's plan of autonomization was implemented and determined character and development of the Soviet Union. The right to self-determination, so to speak a mere slogan in the ideological reservoir of the Bolsheviks, had served its purpose and could be abandoned. It reappeared on the political agenda, when the Soviet empire was falling apart, and nations having been oppressed by the Soviet regime started to restore respectively to newly create self-determined state structures.

\section{Conclusion}

1. The concept: right to self-determination ranked high among the postulates of socialist and social democratic parties, including the Bolsheviks.

2. The proclamation of the right to self-determination was used as a tactical means respectively a political slogan to recruit support for the international fight against imperialism, for the socialist revolution, and for destabilizing and undermining the tsarist regime.

3. Nations and nationalities had the right to secession and independence, but it was subordinated to the higher principle of proletarian internationalism. Thus, the right had a temporary, a transitional character.

4. Revolution and civil war illustrated that in practice the right to self-determination was reduced to the question, whether or not the Bolsheviks were able to control regions in Russia's periphery. Thus many former provinces had to be released into independence. The remaining republics united with the RSFSR in the USSR enjoyed the formal right to self-determination. However, in practice, subordinated to unitary Communist party structures and a unifying ideology the realization of that right was made virtually impossible.

\section{Author Details}

Rudolf A. Mark, Lecturer at Helmut Schmidt Universität/ Universität der Bundeswehr in Hamburg. Research interests: History of the Russian Empire and Soviet Union; history of international relations; History of Europe's and Germany's relations with Central Asia.

Adress: Helmut Schmidt Universität Fakultät GEISO, Holstenhofweg 85, 22008 Hamburg

Email: mark@uni-lueneburg.de 


\title{
LENINO IR BOLŠEVIKŲ KONCEPCIJA DĖL TAUTŲ APSISPRENDIMO TEISĖS
}

Santrauka

\author{
RUDOLF A. MARK
}

\begin{abstract}
Pirmojo pasaulinio karo išvakarèse Centrinès ir Rytų Europos socialistu ir socialdemokratu partijos savo politiniuose postulatuose ir iškeltuose uždaviniuose pradejo kelti prioritetini tautų apsisprendimo teisès klausimą. Tautų apsisprendimo principas buvo naudojamas ir kaip tarptautinès kovos prieš imperializmą, carizmo režimą Rusijos imperijoje priemonè. Nors tautų apsisprendimo teisè buvo neatsiejama nuo bolševikinès ideologijos, ji buvo pavaldi ir aukštesniam proletariato internacionalizmo principui. Bolševikams netekus valdžios, visa tautų apsisprendimo teisè, t.y. teise i atsiskyrimą ir nepriklausomybę, buvo suteikta regionams, kuriuose Sovietai buvo nepajègūs ittvirtinti komunistinio režimo. Taigi buvusios imperijos periferiju regionai, tarp kurių buvo Suomija ir Baltijos šalys, turejjo tapti nepriklausomi. Likusios teritorijos, kurios patyrẻ pralaiméjimą kovoje prieš Raudonają armija, taip pat Sovietinès okupacijos aukos kartu su RTFSR susijungè i SSSR. Čia jos igijo formalią apsisprendimo teisę. Tačiau dèl pavaldumo unitarinėms Komunistų partijos struktūroms ir vyraujančios vieningos ideologijos praktiškai igyvendinti tokią teisę buvo neịmanoma.
\end{abstract}

